\title{
PENERAPAN METODE QUANTUM READING DALAM PEMBELAJARAN BAHASA INDONESIA DI SDN 93 PALEMBANG
}

\author{
Agus Heru \\ Univ. PGRI Palembang \\ Email : agusherupgri@gmail.com
}

\begin{abstract}
Abstrak :Berdasarkan hasil penelitian PTK ini menunjukkan Metode Quantum Reading untuk meningkatkan keterampilan membaca kelas 2 SD Negeri 93 Palembang dapat meningkatkan keterampilan berbahasa Indonesia khususnya kegiatan menyimak, berbicara, membaca dan menulis mencapai 87,50 \%. Aktivitas anak dalam belajar bahasa Indonesia juga ikut meningkat sampai $81,99 \%$. Peningkatan yang ditunjuk-kan melalui penelitian ini dapat menjadi motivasi guru sekolah dasar untuk menggu-nakan Metode Quantum Reading dalam pembelajaran di kelas. Ada beberapa hal yang belum diukur keberhasilannya dalam proses pembelajaran terutama dalam penilaian aktivitas pembelajaran yaitu penyediaan jam kedatangan, pohon prestasi, dan kotak saran. Fasilitas ini disediakan peneliti untuk mendu-kung proses Metode Quantum Reading untuk meningkatkan keterampilan membaca kelas 2 SD Negeri 93 Palembang dan merupakan satu kesatuan dalam pembelajaran Metode Quantum Reading.
\end{abstract}

Kata kunci: Metode Quantum Readingm, Keterampilan Membaca

\section{PENDAHULUAN}

Guru bahasa perlu memahami bahwa dalam pembelajaran bahasa Indonesia lebih dititikberatkan pada performansi berbahasa daripada sekedar memiliki pengetahuan tentang kebahasaan, yakni berupa unjuk kerja mempergunakan bahasa dalam konteks ter-tentu sesuai dengan fungsi komunikatif bahasa. Tarigan (2008:31) mengungkapkan bahwa keterampilan berbahasa dalam bahasa Indonesia meliputi empat aspek, yaitu menyi-mak, berbicara, membaca, dan menulis. Ke-empat aspek tersebut disebut juga sebagai "catur tunggal" keterampilan berbahasa, karena keempat aspek tersebut merupakan satu kesatuan, saling berhubungan, dan tidak bisa dilepaskan, namun berbeda antara satu dengan yang lainnya dan juga berbeda dari segi prosesnya.

Pelajaran bahasa Indonesia dewasa ini ditujukan pada keterampilan siswa meng-gunakan bahasa Indonesia yang baik dan benar dengan konteksnya atau bersifat prag-matis. Dengan kata lain, secara pragmatis-komunikatif bahasa Indonesia lebih meru-pakan suatu bentuk performansi daripada sebagai suatu sistem ilmu. Pandangan ini membawa konsekuensi bahwa pembelajaran bahasa Indonesia harus lebih menekankan fungsi bahasa sebagai alat komunikasi daripada pembelajaran tentang ilmu atau pengetahuan kebahasaan.

Di samping itu, keberhasilan belajar siswa dalam mengikuti proses kegiatan pembelajaran di sekolah sangat 
ditentukan oleh penguasaan keterampilan berbahasa siswa. Siswa yang keterampilan berbahasa-nya kurang, akan mengalami kesulitan dalam mengikuti kegiatan pembelajaran untuk semua mata pelajaran. Siswa akan mengalami kesulitan dalam menangkap dan memahami informasi yang disajikan secara lisan maupun secara tertulis seperti materi pelajaran yang ada dalam berbagai buku pelajaran, buku-buku bahan penunjang, dan sumber-sumber belajar tertulis yang lain, akibatnya, kemajuan belajarnya menjadi lamban.

Oleh karena itu, guru SD dituntut mampu mengembangkan keterampilan berbahasa tersebut. Untuk mencapai tujuan pembelajaran secara efektif, guru perlu menggunakan pendekatan, metode, dan strategi yang tepat. Salah satu pendekatan yang ditawarkan adalah pendekatan yang dapat membawa siswa dalam pembelajaran aktif, kreatif, efektif, dan menyenangkan dengan menggunakan metode Quantum Reading.

Konsep Quantum Reading merupakan perpaduan dari berbagai model belajar, dalam Quantum Reading ada beberapa konsep yang diterapkan, yaitu: a. Mencari AMBaK (apa manfaat bagiku) b. Manfaat dalam membaca buku c. Membangun sugesti dan persepsi dalam membaca buku

Quantum dapat dipahami sebagai “interaksi yang mengubah energi menjadi pancaran cahaya yang dahsyat" (Hernowo, 2004:8). Dalam konteks belajar, Quantum dapat dimaknai sebagai " interaksi yang terjadi dalam proses belajar niscaya mampu mengubah berbagai potensi yang ada dalam diri anda menjadi pancaran atau ledakan gairah (dalam memperoleh halhal baru) yang dapat ditularkan (ditunjukan) kepada orang lain”. Kemahiran membaca merupakan salah satu tujuan dalam pengajaran Bahasa Indonesia karena membaca adalah suatu proses untuk memahami sesuatu yang tersirat atau melihat pikiran yang terkandung di dalam kata-kata tertulis.

Membaca berasal dari kata dasar baca yang artinya memahami arti tulisan (Henry Guntur, 1990:8). Membaca adalah salah satu proses yang sangat penting untuk mendapatkan ilmu pengetahuan. Tanpa bisa membaca, manusia dapat dikatakan tidak bisa hidup di zaman sekarang ini sebab hidup manusia bergantung pada ilmu pengetahuan yang dimilikinya.

Salah satu metode membaca yang cukup menyenangkan untuk meningkatkan kemampuan dan kemauan membaca adalah Quantum Reading, metode ini menggunakan teknik yang menyenangkan dan tidak membebani pembelajar yang ingin meningkatkan kemampuan membaca.Dari konsep pembelajaran ini diharapkan bisa meninghkatkan kemahiran 
dalam membaca teks khususnya dalam bidang studi Bahasa Indonesia.

Data lain diperoleh selama ini dalam pembelajaran membaca cepat, guru menerapkan pembelajaran yang kurang efektif. Selain itu, guru juga belum pernah mengajarkan pembelajaran membaca dengan menggunakan metode gerak mata atau metode membaca cepat yang efektif lainnya. Guru masih terbiasa dengan cara lama dalam pembelajaran membaca cepat, yaitu dengan cara siswa disuruh membaca, kemudian menjawab pertanyaaan atas bacaan.

Dengan artikel ini penulis tertarik untuk membuat hasi penelitian dengan judul, "PENERAPAN METODE QUANTUM READING DALAM PEMBELAJARAN BAHASA $\begin{array}{llll}\text { INDONESIA } & \text { DI } & \text { SDN } & 93\end{array}$ PALEMBANG”.

\section{METODE PENELITIAN}

Penelitian ini berbentuk penelitian tindakan kelas atau PTK yang bersifat kola-borasi. PTK merupakan penelitian tindakan yang dilakukan dengan tujuan memperbaiki mutu praktik pembelajaran di kelas (Kunan-dar, 2010:45). Sejalan dengan itu, Mulyasa (2009:155) menyatakan bahwa tujuan umum PTK adalah (1) memperbaiki dan meningkatkan kondisi serta kualitas pembelajaran di kelas, (2) meningkatkan layanan profesional dalam konteks pembelajaran di kelas, (3) mem-berikan kesempatan kepada guru untuk melakukan tindakan dalam pembelajaran yang direncanakan di kelas, dan (4) membe-rikan kesempatan kepada guru untuk mela-kukan pengkajian terhadap kegiatan pembel-ajaran yang dilakukannya.

PTK ini dilakukan secara bersiklus dan setiap siklusnya terdiri atas empat tahap kegiatan yaitu penyusunan rencana tindakan, pelaksanaan tindakan, observasi, dan refleksi terhadap tindakan yang diberikan. Keempat tahap itu dilakukan dalam setiap siklus. Dengan demikian, pada tiap siklus, peneliti merencanakan kegiatan, melaksanakan, mengobservasi, dan merefleksikan pembelajaran dengan menggunakan Quantum Reading. Hasil refleksi terhadap Siklus I dijadikan dasar memodifikasi dan membuat rencana tindakan Siklus II, selanjutnya dilaksanakan, diobservasikan dan direfleksi-kan pada akhir siklus II.

Untuk kegiatan pada siklus berikutnya dilaksanakan sesuai dengan tingkat keberhasilan yang dicapai oleh siswa. Apabila tingkat keberhasilan siswa pada siklus II belum mencapai ketuntasan belajar, maka hasil refleksi terhadap siklus II dijadi-kan dasar memodifikasi dan membuat ren-cana tindakan pada siklus selanjutnya. 
Tes diberikan berben-tuk tes essay dan tes perfomansi, tergantung keterampilan bahasa apa yang akan diberikan. Tes dilakukan sebanyak tiga kali, yaitu pada akhir setiap siklus (Siklus I, Siklus II, dan Siklus III). Selanjutnya hasil tes pada Siklus I dianalisis. Dari analisis tersebut dapat diketahui kelemahan siswa dalam menyimak, berbicara, membaca dan menulis, yang selanjutnya sebagai dasar untuk meng-hadapi tes siklus berikutnya. Untuk melihat tingkat aktivitas siswa dalam proses pembel-ajaran peneliti menggunakan observasi.

Observasi dilakukan secara langsung seperti yang dikemukan oleh Margono (2005:158--159) yaitu observasi langsung yang merupakan pengamatan dan pencatatan secara sistematik terhadap gejala yang tanpak pada objek pada saat terjadi atau berlang-sungnya peristiwa, sehingga observasi berada bersama objek yang diselidiki. Kegi-atan observasi dilakukan untuk mengetahui keterlibatan siswa dalam kegiatan pembel-ajaran.

\section{HASIL}

Hasil penelitian disajikan berikut ini berdasarkan instrumen penelitian dalam bentuk tes hasil belajar dan hasil aktivitas belajar dengan menggunakan instrumen

Kegiatan ini diamati dengan menggunakan lembar observasi yang berkenaan dengan bagaimana keaktifan, kekreatifan, keefektifan, dan menyenangkan. Hal ini berpedoman pada pendapat Budimansyah (2009:169--171).

Teknik penganalisisan data yang digu-nakan dalam penelitian ini yaitu teknik des-kriptif kualitatif, yaitu suatu teknik penelitian yang bersifat menggambarkan kenyataan atau fakta sesuai dengan data yang diperoleh dengan tujuan untuk mengetahui hasil belajar yang dicapai siswa dan merespon siswa terhadap kegiatan pembelajaran serta aktivitas siswa selama proses pembelajaran berlang-sung.

Indikator keberhasilan dalam penelitian ini adalah (1) ketuntasan keterampilan berba-hasa Indonesia 60, sesuai dengan standar Kriteria Ketuntasan Minimum (KKM) di SD Negeri 93 Palembang dan (2) Rata-rata ketuntasan belajar $\geq 80 \%$ (Sudjana, 2005:109)

observasi. Hasil yang diperoleh dapat dilihat 
Tabel 1 Hasil Pembelajaran Keterampilan

\begin{tabular}{lccccc}
\multicolumn{7}{c}{ Berbahasa } \\
\hline \multicolumn{7}{c}{ Siklus } & A & B & C & D & Rerata \\
\hline $\begin{array}{l}\text { Siklus 1 } \\
\text { Rerata }\end{array}$ & 54,86 & 68,87 & 63,69 & 47,70 & 58,78 \\
Tuntas & 31,81 & 43,48 & 52,10 & 30,43 & 39,46 \\
Siklus 2 & & & & & \\
Rerata & 65,91 & 76,00 & 73,91 & 64,83 & 71,41 \\
Tuntas & 62,5 & 78,91 & 78,26 & 67,21 & 70,47 \\
Siklus 3 & & & & & \\
Rerata & 78,41 & 83,65 & 84,78 & 74,75 & 80,40 \\
Tuntas & 87,5 & 91,3 & 91,3 & 89,4 & 89,88 \\
\hline
\end{tabular}

Keterangan:

A: Menyimak,

B: Berbicara,

C: Membaca

D: Menulis

Tabel 2 Hasil Aktivitas Pembelajaran

Keterampilan Berbahasa

\begin{tabular}{clccc}
\hline \multirow{2}{*}{ No. } & Kegiatan & \multicolumn{3}{c}{ Nilai yang Diperoleh } \\
& Berbahasa & Siklus 1 & Siklus 2 & Siklus 3 \\
\hline 1 & Menyimak & 54,04 & 62,91 & 78,20 \\
2 & Berbicara & 57,06 & 76,90 & 83,15 \\
3 & Membaca & 61,14 & 70,65 & 83,42 \\
4 & Menulis & 54,92 & 62,75 & 83,20 \\
& Jumlah & 227,16 & 273,21 & 327,97 \\
\multirow{2}{*}{ Nilai Rerata } & 56,79 & 68,30 & 81,99 \\
\hline
\end{tabular}

Penerapan Metode Quantum

Reading untuk meningkatkan keterampilan membaca kelas 2 SD Negeri 93 Palembang, hasil sig-nifikan meningkat dari Siklus I hingga Siklus III. Pada pada siklus I, kegiatan pembelajaran ini tampak bahwa pembelajaran dengan menggunakan Metode Quantum Reading untuk meningkatkan keterampilan membaca kelas 2 SD Negeri 93 Palembang belum berjalan dengan lancar dan efektif. Salah satunya indikasinya adalah pembelajaran menghabiskan alokasi waktu secara berle- bihan. Hal ini dikarenakan siswa belum terbi-asa bekerja sama dalam kelompok. Sehingga kegiatan diskusi menghabiskan waktu cukup lama. Selama diskusi berlangsung, tampak kegiatan ini belum berjalan sebagaimana mestinya dan mengakibatkan suasana kelas terkesan gaduh.

Selain itu, siswa belum dapat berkon-sentrasi dengan baik saat membaca dan masih tampak malu-malu dalam menjawab pertanyaan peneliti serta menyampaikan pendapatnya sehingga 
suasana pembelajaran menjadi monoton. Walaupun peneliti telah berusaha memancing partisipasi siswa agar lebih aktif dalam pembelajaran dengan cara bersikap antusias saat memberikan penguatan bagi siswa Namun hal tersebut dirasakan belumlah cukup, mengingat bahwa siswa belum terbiasa menyampaikan pikiran dan pendapatnya dikarenakan tidak percaya diri dan takut salah.

Berdasarkan hasil penelitian dari setiap siklus, maka terlihat bahwa keterampilan menyimak intensif siswa mengalami peningkatan selama diterapkannya Metode Quantum Reading berbahan cerita anak. Pada siklus I didapat hasil nilai rata-rata tes siswa mencapai 54,86 dengan persentase ketuntasan belajar secara klasikal sebesar $31,81 \%$. Apabila merujuk pada referensi yang dikemukakan oleh Aqib, dkk., (2010:41) maka tingkat ketuntasan belajar siswa secara klasikal tergolong dalam kategori kurang baik. Hal ini dikarenakan 15 orang dari 24 siswa belum mencapai ketuntasan belajar. Mengingat kembali kriteria keberhasilan yang belum tercapai pada Siklus I, maka perlu dilanjut-kan pada Siklus II.

Pada siklus II didapat hasil nilai rata-rata keterampilan menyimak intensif siswa meningkat menjadi 65,67 dengan persentase ketuntasan belajar secara klasikal sebesar 62,50\%. Apabila merujuk pada referensi yang dikemukakan oleh Aqib, dkk. (2010:41) maka tingkat ketuntasan belajar siswa secara klasikal tergolong dalam kategori cukup. Jika dibandingkan dengan nilai Siklus I sebelum-nya yaitu 54,86 dengan persentase $31,81 \%$ maka dapat dikatakan bahwa pada siklus II keterampilan membaca intensif siswa mengalami peningkatan yang signifikan.

Namun, pelaksanaan siklus II ini dikatakan belum berhasil karena hasil yang diperoleh masih di bawah indikator yang ditetapkan yaitu $85 \%$ dan masih ada 9 siswa yang belum mencapai KKM, sehingga masih perlu dilan-jutkan pada siklus brikutnya yaitu Siklus III.

Pada siklus III diperoleh hasil nilai rata-rata meningkat menjadi 78,41 dengan persentase ketuntasan belajar secara klasikal sebesar 87,50\%. Apabila merujuk pada referensi yang dikemukakan oleh Aqib dkk., (2010:41) maka tingkat ketuntasan belajar siswa secara klasikal tergolong dalam kate-gori sangat baik. Melihat dari nilai rata-rata dan persentase ketuntasan belajar yang dica-pai siswa, maka pelaksanaan siklus III ini dapat dikatakan berhasil karena sudah men-capai indikator yang ditetapkan yakni $85 \%$. Dari hasil tes pada siklus III dapat diketahui bahwa 21 siswa atau $87,50 \%$ siswa dikatakan telah berhasil dalam pemerolehan keteram-pilan membaca 
intensif. Dari hasil data pada siklus III dapat dinyatakan bahwa Metode Quantum Reading untuk meningkatkan keterampilan membaca kelas 2 SD Negeri 93 Palembang merupakan salah satu pendekatan pembelajaran yang dapat meningkatkan keterampilan menyimak intensif siswa.

Secara keseluruhan dapat disimpulkan bahwa nilai keterampilan membaca intensif siswa setelah menggunakan Metode Quantum Reading mengalami peningkatan, dari Siklus I, dilanjutkan Sklus II, dan Siklus III dengan nilai rata-rata keterampilan menyimak inten-sif siswa mengalami peningkatan. Hal ini disebabkan pendekatan Metode Quantum Reading untuk meningkatkan keterampilan membaca kelas 2 SD Negeri 93 Palembang adalah serangkaian kegiatan pembelajaran mulai dari perencanaan, menentukan strategi, pemilihan materi dan metode pembelajaran, sampai pada penilaian yang memungkinkan siswa mengerjakan kegiatan beragam untuk mengembangkan keterampilan, sikap, dan pemahaman dengan penekanan belajar sambil bekerja sehingga pembelajaran lebih efektif dan menyenangkan.

Untuk itu, kata kunci yang dipegang peneliti adalah adanya kegiatan berpikir (minds-on) dan berbuat (hands-on) sesuai dengan yang dikemukakan oleh Indrawati dan Setiawan (2009:12).
Perilaku negatif yang dilakukan siswa tersebut disebabkan oleh beberapa faktor di antaranya siswa kurang mengetahui pentingnya keterampilan menyimak dan hal ini berdam-pak pada kurangnya minat dan motivasi siswa dalam mengikuti pembelajaran menyi-mak cerita anak. Untuk mengatasinya guru berusaha memotivasi siswa dengan mena-namkan pada siswa bahwa menyimak meru-pakan keterampilan yang sangat penting dan mendasar yang dapat berpengaruh terhadap pemahaman terhadap mata pelajaran lain seperti yang di kemukankan oleh Tarigan (2008:38).

\section{PEMBAHASAN}

Berdasarkan refleksi terhadap tindakan keterampilan berbicara pada Siklus I, hal-hal yang perlu dilakukan untuk siklus selanjut-nya antara lain adalah: (1) peneliti lebih numbuhkan rasa percaya diri siswa agar lebih berani dalam menyampaikan pendapat dan pikirannya, (2) pemberian motivasi bagi siswa untuk lebih aktif dalam belajar dengan memberikan penguatan berupa penguatan verbal, gerak tubuh, dan simbol.

Menurut Pah dan Joni, (dikutip Soetopo, 2010:95) pemberian penguatan dalam kelas akan men-dorong murid meningkatkan usahanya dalam kegiatan belajar mengajar dan meningkatkan hasil belajarnya. (3) pembentukan kelompok belajar yang lebih heterogen dan pemilihan 
ketua kelompok sebagai pemimpin diskusi,

(4) peneliti meminta kepada semua siswa untuk berlatih menggunakan bahasa Indone-sia, (5) pada kegiatan kelompok, peneliti harus lebih banyak memberikan bimbingan, (6) peneliti harus membuat pertanyaan atau soal sesuai kemampuan siswa. Sadhono (2012:58) menyatakan bahwa feedback (umpan balik) merupakan alat utama yang bisa memberitahukan kepada pembelajar mengenai ketepatan dalam meng-gunakan bahasa lisan.

Umpan balik yang diberikan guru diharapkan dapat mengurangi kendalakendala siswa dalam berbicara. Pen-dapat ini didukung oleh Hartono (2012:33) yang mengemukakan bahwa salah satu hal yang harus diperhatikan dalam Metode Quantum Reading adalah memberikan umpan balik yang baik untuk meningkatkan kegiatan belajar.

Berdasarkan refleksi terhadap tindakan pada Siklus II, tindak lanjut yang perlu dila-kukan untuk siklus selanjutnya antara lain: (1) peneliti lebih menumbuhkan rasa percaya diri siswa agar lebih berani dalam menyam-paikan pendapat dan pikirannya, (2) peneliti juga harus menumbuhkan toleransi dan saling menghargai antar kelompok siswa dengan tujuan agar siswa lebih memperha-tikan kelompok lain dalam menyampaikan hasil diskusi kelompok, (3) pemberian moti-vasi bagi siswa untuk lebih aktif dalam belajar dengan memberikan penguatan, berupa penguatan verbal, gerak tubuh, dan simbol. Pemberian penguatan dalam kelas dapat mendorong siswa meningkatkan usahanya dalam kegiatan belajar mengajar dan meningkatkan hasil belajarnya, dan (4) peneliti harus membimbing siswa dalam berbicara. Lovit dikutip Mulyono (2009:183) mengemukakan bahwa kesulitan wicara mencakup kesulitan dalam artikulasi yang berkenaan dengan kejelasan pengujaran kata, penyuaraan yang berkenaan dengan nada dan kelancaran yang berkenaan dengan ketepatan wicara.

Keterampilan berbicara pada Siklus III ini berhasil menuntaskan 21 siswa dari 23 siswa. Berarti masih ada 2 siswa yang belum mencapai ketuntasan belajarnya karena sela-ma proses pembelajaran siswa masih menda-patkan nilai yang rendah di bawah standar KKM yakni 70. Hal ini membuktikan bahwa Metode Quantum Reading dalam pembelajaran bahasa Indonesia dengan materi mengomen-tari persoalan faktual dapat meningkatkan keterampilan berbicara siswa. Pada Siklus III ini hasil aktivitas pembelajaran mencapai nilai rata-rata 83,42 (tergolong sangat Baik).

Berdasarkan refleksi terhadap tindakan keterampilan membaca pada Siklus I tindak lanjut yang perlu dilakukan untuk siklus selanjutnya antara lain: (1) 
peneliti harus lebih memotivasi siswa untuk lebih aktif dalam kegiatan belajar dengan memberikan penguatan baik penguatan dengan ucapan, gerak tubuh maupun pemberian hadiah, (2) peneliti harus lebih banyak memberikan bimbingan pada kegiatan kelompok, (3) peneliti harus memperhatikan seluruh siswa bukan hanya siswa yang aktif saja, (4) sebaiknya peneliti harus menjelaskan cara kerja lebih mendalam kepada siswa mengenai yang mereka lakukan ketika diskusi.

Pada Siklus I diketahui selama proses pembelajaran ada sebagian siswa yang belum serius dalam membaca dan suasana kelas yang agak sedikit ribut yang mengganggu konsentrasi membaca siswa yang lainnya. Burns (dikutip Rahim, 2011:1) mengemuka-kan bahwa kemampuan membaca merupakan sesuatu yang vital dalam suatu masyarakat terpelajar. Namun, siswa yang tidak mema-hami pentingnya belajar membaca tidak akan termotivasi untuk belajar. Karena membaca tidak lain dari memahami arti atau makna yang terkandung dalam tulisan.

Berdasarkan refleksi terhadap tindakan pada Siklus II tindak lanjut yang perlu dila-kukan untuk siklus selanjutnya antara lain: (a) peneliti memotivasi siswa untuk lebih berani dan antusias dalam kegiatan belajar dengan memberikan penguatan baik pengu-atan dengan ucapan, gerak tubuh maupun pemberian hadiah, (b) peneliti harus lebih banyak memberikan bimbingan pada kegi-atan membaca serta kerja kelompok.

Tindakan perbaikan yang telah dilaku-kan pada Siklus II ini sedikit memperbaiki hasil siswa. Walaupun masih ada siswa yang kurang serius dalam membaca hanya mengi-barkan-ngibarkan teks cerita saja. Saat kegi-atan siswa membuat pertanyaan tentang isi cerita, kalimat tanya siswa masih ada yang belum jelas dan masih ada siswa yang bingung bagaimana membuat pertanyaan. Seiring dengan pendapat Rahim (2011:26) Kegiatan siswa membuat pertanyaan sendiri merupakan bagian dari proses pemahaman suatu teks yang lebih bermakna dibandingkan dengan menyuruh siswa melengkapi tugas mereka. Rasa keingintahuan siswa terhadap kebenaran jawaban mereka akan meningkatkan motivasi untuk lebih cermat membaca teks.

Berdasarkan refleksi terhadap tindakan pada Siklus III, hambatanhambatan yang muncul dalam Siklus I dan Siklus II tidak lagi muncul pada Siklus III. Siklus III ini berhasil menuntaskan 21 siswa dari 23 siswa. Berarti masih ada 2 siswa yang belum men-capai ketuntasan belajarnya dikarenakan kurang memahami isi cerita dan dari salah satu siswa ini memang senang dalam pembel-ajaran tapi 
malas dalam membaca sehingga susah memahami bacaan.

Kegiatan pembelajaran menulis pada Siklus I ini tampak bahwa pembelajaran de-ngan menggunakan Metode Quantum Reading belum berjalan secara efektif. Hal ini di karenakan pada saat pembelajaran berlang-sung masih banyak terdapat kekurangan baik yang berasal dari peneliti maupun siswa. Kekurangan yang berasal dari peneliti adalah peneliti kurang dapat memotivasi siswa dalam proses pembelajaran sehingga siswa tampak kurang bersemangat dalam pembel-ajaran.

Selain itu, pada media pembelajaran yang digunakan untuk menempelkan hasil karya puisi siswa kurang maksimal untuk digunakan sehingga pada saat digunakan terjadi beberapa insiden yaitu, media hampir jatuh. Kemudian, terlihat kekurangan peneliti pada saat proses pembelajaran yaitu kurang memperhatikan siswa yang kurang aktif dan hanya fokus pada siswa yang aktif saja.

Di samping itu, pada saat kegiatan diskusi berlangsung, terlihat siswa yang belum terlibat sepenuhnya dalam diskusi. Mereka sibuk dengan teman sekelompoknya dan membahas hal-hal yang tidak berhubungan dengan materi pembelajaran. Selanjutnya, pada saat kegiatan menuis puisi siswa masih terlihat binggung dan belum sepenuhnya paham. Hasil karya puisi siswa masih dalam kategori kurang baik.

Berdasarkan refleksi terhadap tindakan pada Siklus I tindak lanjut yang dilakukan untuk siklus selanjutnya antara lain: (a) memberikan siswa perhatian secara merata khususnya lebih fokus kepada siswa yang kurang aktif, (b) pemberian moti-vasi siswa untuk lebih aktif dalam belajar dengan memberikan penguatan berupa penguatan dengan gerak, tubuh, ucapan dan simbol, (c) pada pertemuan berikutnya peneliti juga mempersiapkan media untuk menempelkan hasil karya puisi siswa, dan (d) pada kegiatan kelompok, peneliti harus lebih banyak memberikan bimbingan sehingga seluruh anggota kelompok dapat lebih serius dalam berdiskusi.

Berdasarkan hasil pengamatan yang tergambar pada diagram di atas, dapat dilihat bahwa hasil pengamatan terhadap aktivitas siswa mengalami peningkatan dari Siklus I, dilanjutkan Siklus II, dan Siklus III. Pada Siklus I, hasil aktivitas siswa dalam proses pembelajaraan mencapai nilai 54,92 (tergo-long kurang).

Selanjutnya pada Siklus II, hasil pengamatan kegiatan siswa dalam proses pembelajaran mencapai 62,75 (tergo-long cukup). Pada Siklus III, hasil penga-matan 
kegiatan siswa dalam proses pembel-ajaran mencapai 83,20 (tergolong baik).

Dari hasil observasi Siklus I diketahui bahwa dalam proses pembelajaran menulis puisi melalui Metode Quantum Reading masih ditemukan prilaku siswa yang positif dan negatif. Prilaku positif terlihat pada beberapa siswa yang aktif dalam mengikuti proses pembelajaran. Selanjutnya dapat dilihat bahwa siswa yang merasa senang pada saat membuat puisi bahkan siswa semakin tertarik pada saat peneliti meminta siswa untuk menempelkan karya puisinya ditempat yang telah disediakan, sehingga siswa semakin merasa senang disetai dengan media pembel-ajaran yang digunakan oleh peneliti.

Sedang-kan prilaku negatif ditunjukan oleh beberapa siswa yang tidak memperhatikan dan mengajak temannya berbicara pada saat proses pembel-ajaran berlangsung, kemudian ada beberapa siswa yang belum membuat puisi dengan memperhatikan unsur-unsur dalam pemben-tukan puisi. Gambar berikut menunjukkan aktivitas siswa menulis dan menempelkan karya mereka pada tempat yang sudah dise-diakan.

Selanjutnya pada Siklus II, prilaku siswa sudah mengalami peningkatan dibandingkan Siklus I sedangkan pada Siklus III sudah ter-jadi peningkatan yang sangat signifikan dibanding Siklus I dan
Siklus II. Dari analisis data yang diperoleh dapat dijelaskan bahwa terjadinya peningkatan dalam prilaku siswa yang menunjukkan prilaku kearah fositif. Siswa yang sebelumnya kurang bersemangat, tidak memperhatikan, cenderung asik dengan teman sebangkuya sudah terlihat bersema-ngat, tertarik untuk memperhatikan pada saat proses pembelajaran berlangsung.

\section{KESIMPULAN}

Berdasarkan hasil penelitian dan pem-bahasan di atas disimpulkan bahwa dengan menggunakan Metode Quantum Reading untuk meningkatkan keterampilan membaca kelas 2 SD Negeri 93 Palembang dapat meningkatkan hasil pembelajaran dan aktivi-tas siswa dalam proses pemblajaran pada mata pelajaran bahasa Indonesia. Hasil nilai rata-rata keterampilan berbahasa Indonesia (menyimak, berbicara, membaca dan menu-lis) siswa pada siklus I, siklus II, dan siklus III mengalami peningkatan yang signifikan. Pada siklus I nilai rata-rata siswa 39,47 \% dan pada siklus II nilai ratarata siswa men-capai $67,21 \%$.

Pada siklus III nilai rata-rata siswa meningkat lagi mencapai 89,40\%. Berdasarkan data ini menunjukkan bahwa Metode Quantum Reading untuk meningkatkan keterampilan membaca kelas 2 SD Negeri 93 Palembang dapat 
meningkatkan keterampilan berbahsa Indonesia siswa di sekolah dasar.

Peningkatan hasil nilai rata-rata kete-rampilan berbahasa Indonesia siswa juga didukung oleh hasil pengamatan aktivitas siswa selama proses pembelajaran yang juga mengalamai peningkatan. Pada Siklus I, keaktifan siswa dalam belajar mencapai 56,79 \% (cukup), pada Siklus II meningkat menjadi $68,30 \%$ (baik), dan pada Siklus III meningkat lagi menjadi $81,99 \%$ (sangat baik). Karena itu, melalui penerapan Metode Quantum Reading

\section{DAFTAR PUSTAKA}

Arikunto, Suhardjono, dan Supardi. 2010. Penelitian tindakan kelas. Jakarta: Bumi Aksara.

Asmani, Jamal Ma'mur. 2011. 7 tips aplikasi PAKEM (Pembelajaran Aktif, Kreatif, Efektif, dan Menyenangkan). Yogjakarta: DIVA Press.

Budimansyah, Darsim, Suparlan, Meirawan, Danny. 2008. PAKEM (Pembelajaran aktif, kreatif, efektif, dan menyenang-kan). Bandung: Genesindo.

Deporter, B, dkk (2003).Quantum Teaching: Mempraktektekan Quantum Learning Di Ruang-ruang Kelas, Bandung: Kaifa

Fatah, Nanang (2008). Landasan Manajemen Pendidikan. Bandung: Remaja Rosdakarya

Hernowo (Ed). (2004). Quantum Reading: Cara Cepat nan Bermanfaat untuk merangsang munculnya potensi membaca. Bandung : Mlc untuk meningkatkan keterampilan membaca kelas 2 SD Negeri 93 Palembang dapat melatih kemandirian dan keterampilan siswa, sehingga guru tidak dijadikan sebagai pusat dalam pembelajaran tetapi guru hanya sebagai fasilitator.

Mulyasa, (2008). Menjadi Guru profesional: Menciftakan Pembelajran yang kreatif dan menyenangkan. Bandung: Remaja Rosda Karya

Gabler, Burt dan Nadia F. Scholnick. 1995. Listen-in listening/speaking attack strategies for students of ESL. New York: St. Martin's Press.

Inovatif kreatif efektif dan menyenang-kan. Jakarta: Bumi Aksara. Indrawati dan Wanwan. 2009.

Pembelajaran aktif, kreatif, efektif, dan menyenang-kan untuk guru SD. Jakarta: PPPPTK.

Kunandar. 2011. Langkah mudah penelitian tidakan kelas. Jakarta: Rajawali Pers.

Mulyasa. 2009. Menjadi guru profesional. Bandung: PT Remaja Rosdakarya. Mulyono, Abdurrahman. 2009. Pendidikan bagi anak berkesulitan belajar. Jakarta: Rineka Cipta. 
Nunan, David. 1991. Language teaching methodology a textbook for teachers. Great Britain: Prentice Hall International (UK) Ltd. Nurgiyantoro, Burhan. 2012. Penilaian pem-belajaran basaha berbasis kompetensi. Yogyakarta. BPFE. Rahim,

Farida. 2011. Pengajaran membaca di sekolah dasar. Jakarta: Bumi Angkasa.

Rost, Michael. 1991. Classroom technique and resources: Listening in Action.

Printice Hall. Rusman. 2010. Model-model pembelajaran mengembangkan profesionalisme guru. Bandung: Rajagrafindo Persada.

Saddhono, Slamet. 2012. Meningkatkan kete-rampilan berbahsa (teori dan aplikasi). Bandung: Karya Putra Darwati.

Slamet, Y, St. 2008. Dasar-dasar pembelajaran bahasa dan sastra Indonesia di sekolah dasar.Surakarta: UNS dan UPT Penerbitan dan Percetakan.

Subana, dan Sunarti. 2011. Strategi belajar mengajar bahasa Indonesia. Bandung: Pustaka

Setia. Sumadayo, Samsu. 2011. Strategi dan teknik pembelajaran membaca. Yogyakarta: Graha Ilmu. Sumadayo,

Samsu. 2013. Penelitian tindakan kelas. Yogyakarta: Graha Ilmu.

Tarigan, Henry Guntur. 2008. Berbicara sebagai suatu keterampilan berbahasa. Bandung: Angkasa. Tarigan, Henry Guntur. 2008. Menyimak sebagai suatu keterampilan berbahasa. Bandung: Angkasa. Uno, 